University of Warwick institutional repository: http://go.warwick.ac.uk/wrap

This paper is made available online in accordance with publisher policies. Please scroll down to view the document itself. Please refer to the repository record for this item and our policy information available from the repository home page for further information.

To see the final version of this paper please visit the publisher's website. Access to the published version may require a subscription.

Author(s): Peachey, T., Hawley, C. A., Cooke, M., Mason, L. and Morris, $\mathrm{R}$.

Article Title: Minor head injury in the Republic of Ireland: evaluation of written information given at discharge from emergency departments

Year of publication: 2011

Link to published article:

http://dx.doi.org/10.1136/emj.2010.093872

Publisher statement: None 


\title{
Minor head injury in the Republic of Ireland: evaluation of written information given at discharge from emergency departments
}

\author{
Tom Peachey, ${ }^{1}$ Carol A Hawley, ${ }^{1}$ Matthew Cooke, ${ }^{1}$ Lynda Mason, ${ }^{1}$ Richard Morris ${ }^{2}$
}

- An Additional appendix is published online only. To view this please visit the journal online (http://emj.bmj.com/).

${ }^{1}$ Emergency Care and Systems Improvement Group, Warwick Medical School, University of Warwick, Coventry, UK ${ }^{2}$ Headway, Nottingham, UK

\section{Correspondence to} Dr Carol Hawley, Principal Research Fellow, Emergency Care and Systems Improvement Group, Health Sciences Research Institute, Warwick Medical School, University of Warwick, Coventry CV4 7AL, UK; c.a.hawley@warwick.ac.uk

Accepted 18 July 2010 Published Online First 10 November 2010

\begin{abstract}
Most patients presenting to the emergency department with minor head injuries are discharged with written information. Here the quality of minor head injury discharge leaflets in the Republic of Ireland is evaluated against a nationally accepted template. There was great variability in leaflet content. Most provided minimal information on emergency symptoms but $60 \%$ contained no information on post-concussional symptoms. No leaflet was available in audio-format or languages other than English. Information provided in minor head injury leaflets should be improved and standardised across Ireland.
\end{abstract}

\section{INTRODUCTION}

Of the 1.2 million emergency department (ED) attendances in Ireland every year, ${ }^{1}$ up to $10 \%$ are due to head injuries. ${ }^{2}$ Eighty per cent of patients with head injuries are discharged directly from the ED. ${ }^{2}$ Written information should be used to supplement verbal discharge instructions ${ }^{3}$ as intracranial haemorrhages are occasionally missed ${ }^{4}$ even with CT scanning. ${ }^{5}$ Furthermore, post-concussional symptoms (PCS) are common and may persist beyond 1 year post-injury in half of minor head injury (MHI) patients. ${ }^{6}$ Although individual Irish EDs use different sources to inform protocols, many use UK derived advice. ${ }^{7}$ In the UK, NICE and SIGN provide head injury guidelines that include templates for written discharge information. ${ }^{89}$

\section{METHODS}

Irish hospitals with a full ED were identified on the Health Service Executive (Ireland) website. In 2009 we contacted the lead nurse at all 35 EDs, asking for their MHI discharge leaflet. A short questionnaire explored supplemental information on whether there were separate information leaflets for babies/toddlers, children, adults and carers; and if the leaflets were available in other languages, audio-format, large print or Braille. Non-responders were first followed up with another letter, then telephoned.

A comprehensive MHI leaflet was created based on NICE and SIGN guidelines ${ }^{8} 9$ before any analysis was undertaken. Information provided in each leaflet was evaluated against this template leaflet, which contained four pieces of general advice, 11 emergency symptoms and action to take if these occur. Eight symptoms indicative of PCS were also listed, plus eight advice items to aid recovery. Leaflets scored one point per item out of a total of 31.

\section{RESULTS}

All 35 (100\%) EDs provided data and sent their leaflets. Sixteen EDs (46\%) used separate leaflets for children, only one used a different leaflet for babies/ toddlers. Nineteen $(54 \%)$ provided separate information for carers, two did not provide a leaflet for the patient him/herself. No ED provided leaflets in Braille, audio-format or languages other than English, although two offered translation services. One ED offered their leaflet in large print.

The most comprehensive leaflet scored 26 out of 31 , five scored 3 (mean score: 10.86, $\mathrm{SD}=7.43$ ). Table 1 lists the provision of general advice. Table 2 details the inclusion of each emergency symptom. The mean number of emergency symptoms listed was 5.5 (range: $0-9, \mathrm{SD}=2.59$ ). Advice regarding vomiting was highly variable; 25 (71\%) leaflets asked the patient to return to the $\mathrm{ED}$ if there is 'vomiting', others gave conditions such as 'continued', 'frequent' or 'excessive'. Twenty-seven (77\%) EDs provided a direct-line telephone number.

Table 3 shows the number of leaflets containing each post-concussive symptom and advice to aid recovery. Two leaflets included all eight PCS symptoms, 21 (60\%) contained none.

\section{DISCUSSION}

Every ED in Ireland used written leaflets to give to MHI patients on discharge. There was considerable variability in the amount and quality of information provided. Many leaflets lacked important information, particularly regarding PCS features. These findings are consistent with UK studies. ${ }^{10}$

Fourteen leaflets (40\%) were very brief, providing patients with four or fewer emergency symptoms which should trigger a return to the ED. However, the majority cited vomiting, severe headache, drowsiness and visual disturbances as causes for contacting or returning to the ED. Advice regarding specific symptoms was variable, particularly for

Table 1 General advice

\begin{tabular}{lc}
\hline Advice item & $\begin{array}{l}\text { Number (\%) of } \\
\text { MHI leaflets including } \\
\text { this item (n=35) }\end{array}$ \\
\hline Have a carer to stay with you: & $16(45.7)$ \\
For $24 \mathrm{~h}$ & $4(11.4)$ \\
For $48 \mathrm{~h}$ & $1(2.8)$ \\
For the next day or so & $8(22.9)$ \\
Unspecified & $3(8.5)$ \\
Show leaflet to a responsible adult & $3(8.5)$ \\
Stay near a telephone & $10(28.6)$ \\
Some symptoms are common & $12(34.3)$ \\
\hline
\end{tabular}

$\mathrm{MHI}$, minor head injuries. 
Table 2 Clinical events triggering a return to the ED

\begin{tabular}{|c|c|c|c|}
\hline & $\begin{array}{l}\text { Number }(\%) \text { of } \\
\text { leaflets including } \\
\text { this feature }(N=35)\end{array}$ & & $\begin{array}{l}\text { Number }(\%) \text { of } \\
\text { leaflets including } \\
\text { this feature }(\mathrm{N}=35)\end{array}$ \\
\hline Features of deteriorating GCS & & Indications of basal skull fracture & \\
\hline Drowsiness or difficult to wake & $30(85.7)$ & Focal neurology & \\
\hline Confused or disoriented & $13(37.1)$ & Limb weakness & $15(42.9)$ \\
\hline Vomiting & $33(94.3)$ & Advice on emergency features & \\
\hline Fit & $18(51.4)$ & If yes to any of these, ring or return to ED & $19(54.3)$ \\
\hline Neuropsychological impairment & & If worried about anything, ring ED & $15(42.9)$ \\
\hline \multirow[t]{2}{*}{ Speech slurred/problems with speech } & $2(5.7)$ & ED telephone number given & $27(77.1)$ \\
\hline & & If worried, take patient straight back to ED & $27(77.1)$ \\
\hline
\end{tabular}

ED, emergency department; GCS, Glasgow Coma Scale; ICP, intracranial pressure.

vomiting. Present guidance recommends that any vomiting should trigger a return to the ED. ${ }^{8} 9$

Only 11 leaflets (31\%) contained information on emergency features, PCS and general advice. Thirty-three (94\%) included some emergency information, but $21(60 \%)$ omitted PCS information. Only eight leaflets advised the patient to visit their family practitioner (GP) if symptoms persist. Provision of PCS information in leaflets may avoid unnecessary GP attendances.

Advice to aid recovery was provided by 21 (60\%) leaflets, although half $(48 \%)$ provided only one or two pieces of advice. Only $57 \%$ of EDs used leaflets advising patients to avoid alcohol.

None of the EDs provided leaflets in languages other than English or in audio-format. An inability to read or understand the information could delay recovery or lead to unnecessary reattendance to the $\mathrm{ED}$.

Table 3 Post-concussive features and advice to aid recovery

\begin{tabular}{ll}
\hline Item & $\begin{array}{c}\text { Number (\%) of MHI } \\
\text { leaflets including this } \\
\text { feature ( } \mathbf{n}=\mathbf{3 5})\end{array}$ \\
\hline Post-concussive features & \\
Mild headache & $14(40)$ \\
Dizziness & $11(31.4)$ \\
Memory problems & $10(28.6)$ \\
Poor concentration & $14(40)$ \\
Irritability & $6(17.1)$ \\
Easily annoyed & $7(20)$ \\
Fatigue & $13(37.1)$ \\
Poor sleep & $10(28.6)$ \\
Advice to aid recovery & \\
Don't worry if you have any of these & $2(5.7)$ \\
(PCS) symptoms & $7(20)$ \\
These symptoms should clear up in \\
time without treatment \\
If symptoms persist see your GP \\
Take plenty of rest & $8(22.9)$ \\
Do not take any alcohol & $12(34.3)$ \\
Do not take drugs & $20(57.1)$ \\
Do not play contact sports & $2(5.7)$ \\
Do not drive until you feel you have \\
completely recovered
\end{tabular}

\section{CONCLUSIONS}

Many MHI leaflets omit important information and there is wide variation between EDs. These leaflets should be improved and standardised. A comprehensive MHI leaflet (appendix 1) is now freely available from the NHS Evidence website, ${ }^{11}$ and could be used across all Irish EDs.

Acknowledgements We thank the lead nurses and other staff at the EDs for their cooperation with this study. We thank Headway, the Brain Injury Association, for working with us to develop the leaflet.

Funding The University of Warwick Undergraduate Research Scholarship Scheme awarded TP a scholarship to carry out the study.

Competing interests None.

Contributors All authors contributed to the research. TP and CAH wrote the paper; other authors commented on the paper and the revisions.

Provenance and peer review Not commissioned; externally peer reviewed.

\section{REFERENCES}

1. Health Service Executive. Health status of the population of Ireland. Health Service Executive, Ireland. 2008. http://www.hse.ie/eng/services/Publications/Health Protection/Public Health /Health Status of the Population of Ireland 2008.html

2. Kay A, Teasdale G. Head injury in the United Kingdom. World J Surg 2001;25:1210-20.

3. Taylor D, Cameron PA. Discharge instructions for emergency department patients: what should we provide? J Accid Emerg Med 2000;17:86-90.

4. Rockswold GK, Pheley PJ. Patients who talk and deteriorate. Ann Emerg Med 1993;22:1004-7

5. Stiell IG, Wells GA, Vandemheen $\mathrm{K}$, et al. Variation in ED use of computed tomography for patients with minor head injury. Ann Emerg Med 1997;30:14-22.

6. Thornhill S, Teasdale GM, Murray GD, et al. Disability in young people and adults one year after head injury: prospective cohort study. BMJ 2000;320:1631-5.

7. Health Service Executive. Review of acute hospital services in HSE Mid-West. An action plan for acute and community health services. Health Service Executive, Ireland. April 2008. http://www.hse.ie/eng/services/Publications/services/Hospitals/ midwestreport.html

8. National Institute for Health and Clinical Excellence (NICE). Head injury: triage, assessment, investigation and early management of head injury in infants, children and adults. London: National Collaborating Centre for Acute Care, 2007.

9. Scottish Intercollegiate Guidelines Network (SIGN). Early management of patients with a head injury: a national clinical guideline. Edinburgh: Scottish Intercollegiate Guidelines Network, 2009.

10. Kerr J, Swann IJ, Pentland B. A survey of information given to head-injured patients on direct discharge from emergency departments in Scotland. Emerg Med J 2007:24:330-2.

11. http://www.library.nhs.uk/EMERGENCY/ViewResource.aspx?resID=3176478; tablD $=2928$ cat $\mid D=6090$ (accessed Feb 2010). 


\section{EM]}

\section{Minor head injury in the Republic of Ireland: evaluation of written information given at discharge from emergency departments}

Tom Peachey, Carol A Hawley, Matthew Cooke, et al.

Emerg Med J 2011 28: 707-708 originally published online November 10,2010

doi: 10.1136/emj.2010.093872

Updated information and services can be found at:

http://emj.bmj.com/content/28/8/707.full.html

\section{These include:}

References This article cites 6 articles, 3 of which can be accessed free at: http://emj.bmj.com/content/28/8/707.full.html\#ref-list-1

Email alerting Receive free email alerts when new articles cite this article. Sign up in service the box at the top right corner of the online article.

$\begin{array}{cc}\text { Topic } & \text { Articles on similar topics can be found in the following collections } \\ \text { Collections } & \text { Trauma (789 articles) } \\ \text { Trauma CNS / PNS (212 articles) }\end{array}$

Notes

To request permissions go to:

http://group.bmj.com/group/rights-licensing/permissions

To order reprints go to:

http://journals.bmj.com/cgi/reprintform

To subscribe to BMJ go to:

http://group.bmj.com/subscribe/ 